\title{
Perceived Injustices in Forest Policy Interventions are Causes of Forest Resources Degradation and Loss in Ghana: A Review
}

\author{
Richard Kyere-Boateng1,2,3, Michal V. Marek ${ }^{2,4}$, Mikuláš Huba1, Tatiana Kluvankova5* \\ ${ }^{1}$ Department of Spatial Planning, Institute of Management, Slovak University of Technology in Bratislava, Vazovova 5, 81243 \\ Bratislava, Slovakia \\ ${ }^{2}$ Department of the Human Dimensions of Global Change, Global Change Research Institute, Czech Academy of Sciences, Brno, \\ Bělidla 986/4a, 60300 Brno, Czech Republic \\ ${ }^{3}$ Department of Geographic Science, University of Energy and Natural Resources (UENR), 214, Sunyani, Ghana \\ ${ }^{4}$ SlovakGlobe Institute of Management, Slovak University of Technology in Bratislava, Vazovova 5, 81243 Bratislava, Slovakia \\ ${ }^{5}$ SlovakGlobe: Institute of Forest Ecology Slovak Academy of Sciences, Institute of Management, Slovak University of Technology \\ Vazovova 5, 81243 Bratislava, Slovakia \\ Email: mikulas.huba2@gmail.com,marek.mv@czechglobe.cz, tana@cetip.sk,kyereboateng.r@czechglobe.cz
}

How to cite this paper: Kyere-Boateng, R., Marek, M. V., Huba, M., \& Kluvankova, T. (2021). Perceived Injustices in Forest Policy Interventions are Causes of Forest Resources Degradation and Loss in Ghana: A Review. Open Journal of Forestry, 11, 171-191. https://doi.org/10.4236/ojf.2021.113012

Received: April 26, 2021

Accepted: June 4, 2021

Published: June 7, 2021

Copyright $\odot 2021$ by author(s) and Scientific Research Publishing Inc. This work is licensed under the Creative Commons Attribution International License (CC BY 4.0).

http://creativecommons.org/licenses/by/4.0/

(c) (i) Open Access

\begin{abstract}
Forests provide diverse co-benefits, including livelihoods enhancement, poverty alleviation, and biodiversity conservation and ecosystem services such as climate mitigation. Consequently, Ghana has embraced several global, regional, national, and local forest policy interventions to safeguard its forest resources' sustainable management. However, the forest policy interventions have not adequately addressed the co-benefits issues of forest resources leading to several forest illegalities that drive forest resources degradation and loss. These forest policies and interventions on the ground primarily favour carbon stocks enhancement and sequestration activities for carbon mitigation purposes compared to the benefits, access and rights that forest-dependent people and communities are supposed to derive from forest resources. These perceived injustices in the access and distribution of forest resources have culminated into all forms of forest illegalities driving Ghana's forest resources into massive degradation and loss. Currently, Ghana is experiencing a $2 \%$ rate of annual deforestation and forest degradation, which translates into approximately $135,000 \mathrm{ha} /$ year of forest cover loss due to anthropogenic causes. Our review is based on relevant and critical forest documents, and scientific peer-reviewed papers on Ghana's forest policy interventions and dynamics recently published. The information gathered enabled us to highlight the perceived injustices in the forest policy interventions and their effects on forest resources. Unjust forest resources sharing and distribution are critical
\end{abstract}


drivers of forest resources degradation and loss. We thus offer lessons for remedying the unfair distribution and injustices to promote equitable forest resources rights and benefit access to local forest-dependent people. It is expected that this review will offer and assist forest policy, intervention spatial and other planners and designers to find a possible way forward to avoid nature degradation, including biodiversity loss, to resolve perceived injustices in the forestry sector, to use adequate all ecosystem services provided by forests as well as to promote local livelihood and sustainability.

\section{Keywords}

Ghana, Forest Policy Intervention, Deforestation and Biodiversity Degradation, Climate Mitigation, Sustainability

\section{Introduction}

Globally, forests provide various direct and underlying services, benefits and goods to satisfy human needs and wants (Führer, 2000; Montesinos, 2019). The UN Food and Agriculture Organisation [FAO] report indicates that forests contain over three-quarters of the global terrestrial biodiversity and provide over a billion people with different ecosystem services [ESs] (FAO, 2018). Forest provisioning ESs, in particular, serve as critical bedrock for human sustenance (Prip, 2018), whereas regulating services also help in climate regulation and mitigation of current global warming (Ojha et al., 2019). Additionally, forests contribute significantly to the carbon cycle process, which helps mitigate anthropogenic carbon emissions that cause global warming (Pan et al., 2011; Hurteau et al., 2019; Yaduv et al., 2018). Hence the recent global climate change actions, approaches and policies aimed at mitigating carbon emissions have focused mainly on forests (Ojha et al., 2019). However, forests biodiversity and ESs are severely affected due to persisting natural and anthropogenic perturbations (Führer, 2000). The non-timber forest products [NTFPs], including food, fuelwood, fiber, mushrooms, and wild fruits, among others from the forest (Boon \& Ahenkan, 2012), are critical sources of livelihood opportunities required by forest-dependent people.

Most Ghanaian farmers use off-reserve forests for cocoa plantation, which provide them with both income and employment to enhance their livelihoods (Benefoh et al., 2018). However, the fear is that as off-reserve forest and other landscapes become scarce, there is the tendency that the actual forest reserves would be encroached for cocoa farming expansion (Benefoh et al., 2018). For example, between 2000-2010, Ghana recorded an average annual deforestation rate of $1.7 \%$ in the southern high forest zones of cocoa-producing areas, where between 2000 and 2015, close to 110,000 ha of forests were lost to agricultural lands annually (O'Sullivan et al., 2018). Likewise, the forest conversion for cocoa production accounted for $54.6 \%$ and $77.8 \%$ in the closed forest and open forest 
loss, respectively (Benefoh et al., 2018). Also, farmers clear new forests for food crops production annually because the crops could not grow well under the cocoa canopy (Acheampong et al., 2018), a situation leading to forest landscapes being converted for food and cash crops (cocoa and palm oil) production, which provide income sources and employment avenues (Tilahun et al., 2016; Ahenkan and Boon, 2010; O'Sullivan et al., 2018). Ghana's forests and other vegetations are used to produce many foods and cash crops production which threaten the conservation and sustainability of the forest in general. Figure 1 illustrates an enhanced land use cover map of Ghana, showing the different vegetations and land use activities. The mono cocoa and shaded cocoa farming dominate the country's close and open forest zones, while annual crop production is spread throughout the other land vegetations.

In Ghana, land ownership could be categorised into three categories: customary ownership, $78 \%$, state or public ownership, $20 \%$, and shared ownership, $2 \%$ constituting the country's total land area (Ministry of Lands and Natural Resources, 2016). Predominantly lands in Ghana are governed by customary and statutory laws (Bukari \& Kuusaana, 2018). While family heads manage the family

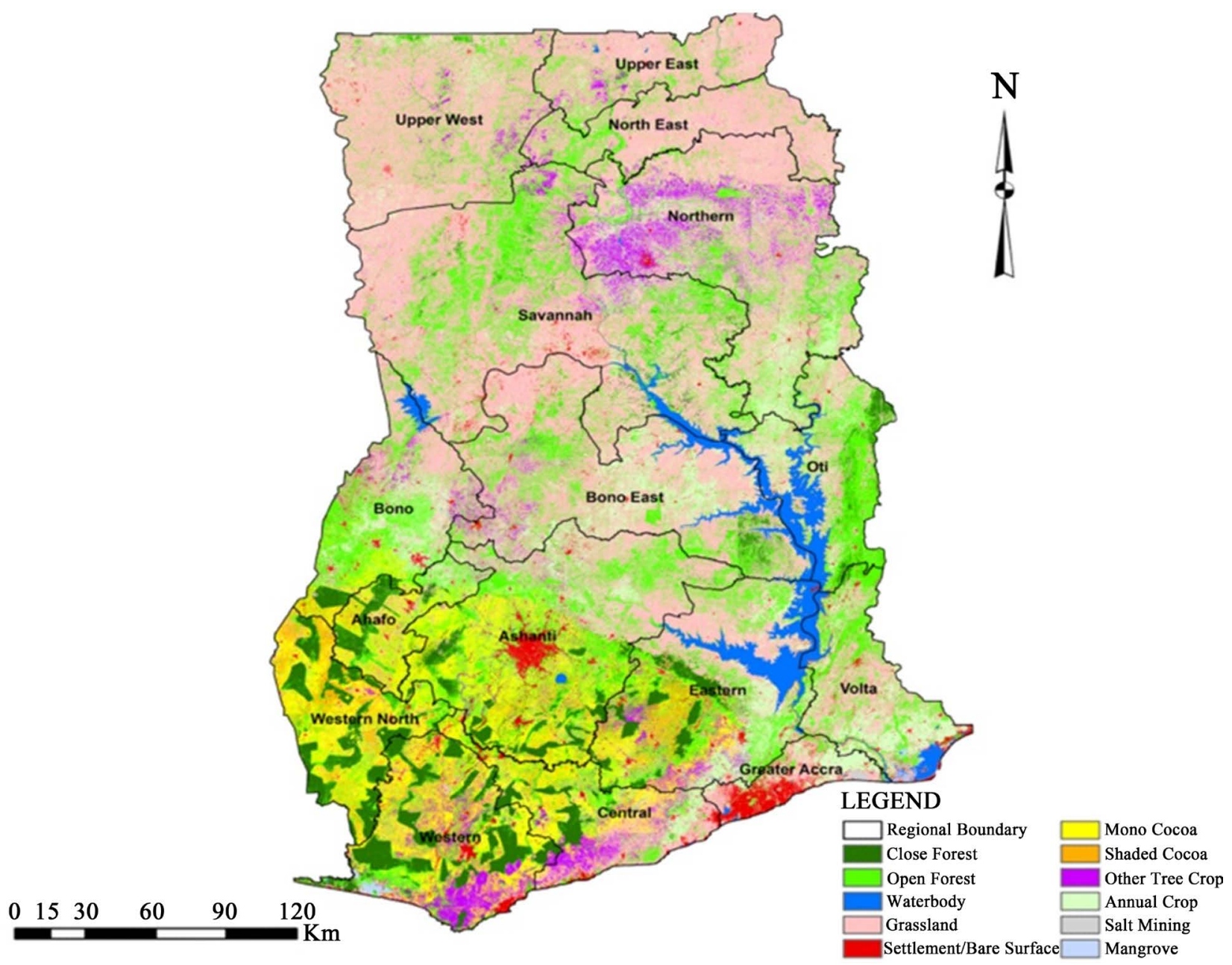

Figure 1. Enhanced land use cover map of Ghana (Forestry Commission, 2019). 
lands under the customary ownership, the state holding lands, including some forest reserves, are managed by the Forestry commission [FC] on behalf of the state (Bukari \& Kuusaana, 2018). In Ghana, all forest lands except forest plantations owned by private investors are vested in the state on behalf of the citizenry (Dumenu et al., 2014). Although farmers and landowners could engage in tree plantations and have the exclusive right of benefits, all naturally occurring trees existing in both the reserves and off-reserves are owned by the state with exclusive and absolute user rights (Dumenu et al., 2014). For instance, the rights to exploit timber are exclusively vested in the state for regulating logging concessions, logging procedures, and appropriating all accruing revenue (O'Sullivan et al., 2018). This makes the local communities whose lands and farms these economic trees occur naturally find the current and existing tree tenure and benefit-sharing arrangements as unfair and inequitable.

Consequently, the inequitable benefit-sharing and lack of clear tree tenure have perpetuated illegal logging, creating disincentives for farmers and landowners to keep trees on their farms, as well as not getting involved in tree planting projects (O'Sullivan et al., 2018). Given the widespread degradation on the on-reserve and off-reserve alike, the state has embarked on several interventions to achieve forest restoration through forest plantation under the direction of the Forestry Commission. However, the perceived injustices that emanate from forest policies and the various interventions make forest restoration and management regimes highly challenging. This review highlights the various perceived injustices inherent in Ghana's forest policy interventions catalysing Ghana's forest degradation and loss. We argue that the purported and perceived injustices are the key drivers of forest resources degradation and loss. Consequently, the review's key objective is to explore the literature on forest policy interventions that have operated in Ghana and highlight the issues, dynamics, and linkages that mediate and reinforce the perceived forest injustices.

In the recent past, private investors and companies' involvement in forest carbon plantation has soared due to the perceived financial benefits and opportunities inherent in the projects. The private companies' huge attraction into the forest carbon plantation had not happened without its attendant hardship on local forest communities and farmers. The greater motivation that attracted many investors into forest carbon plantation was due to the shift in old forest governance to ensure increased forests cover for enhanced carbon stocks and sequestration potentials for climate mitigation purposes. Thus, forest governance's strategies must reduce deforestation and forest degradation related emissions (Forestry Commission, 2015). A key example of such carbon mitigation interventions is the REDD+ (reducing emission from deforestation and forest degradation, forest conservation and enhancement of carbon stocks) which Ghana joined in 2008 to manage and conserve forests sustainably and enhance her forests carbon stocks (O’Sullivan et al., 2018; Asiyanbi et al., 2017; Kansanga \& Luginaah, 2019). Thus, the REDD+ mechanism was intended to create finan- 
cial incentives for developing countries such as Ghana to use the forest for carbon storage by reducing emissions emanating from forest landscapes. Also, other national forest carbon interventions, namely: The Community Resource Management Areas [CREMAs], Modified Taungya System [MTS], National Forest Plantation and Development Programme [NFPDP], among others, have been operated in the Ghanaian High Forest Zones [HFZs] primarily to manage and conserve forests for enhanced carbon stocks and livelihood opportunities (Baruah et al., 2016; Oduro et al., 2015; Acheampong et al., 2016). These tree plantation activities are ongoing in the degraded on-reserves and off-reserves forests in many parts of Ghana. The private plantations investors receive funding under the Ghana REDD+ mechanism for forest restoration, management, and enhance carbon stocks (Forestry Commission, 2015). REDD+ mechanism is expected to generate co-benefits in livelihoods enhancement, poverty alleviation, biodiversity conservation and carbon benefits (Forestry Commission, 2015; Dumenu et al., 2014). However, these private investors' activities under the REDD+ are primarily motivated by the financial rewards and incentives expected to be generated from the carbon revenue compared to other co-benefits provisions from these interventions (Kansanga \& Luginaah, 2019; Saeed et al., 2018, Andoh \& Lee, 2018). The supposed carbon market incentives expected to be accrued from carbon forest plantation activities and other afforestation schemes have not adequately addressed the inherent forest tenure, land access and benefit-sharing dynamics (Dumenu et al., 2014; Oduro et al., 2015; Forestry Commission, 2016; Andoh \& Lee 2018; Kansanga \& Luginaah, 2019). These carbon forest plantation investors have brought about several injustices to the forestlands' original occupants, thus denying them of lands to farm. The carbon forest plantation is a profitable venture attracting a lot of private investors. To date, these plantations and afforestation developments and REDD+ interventions have not adequately emphasised and addressed the pressing issues such as land ownership rights, tree and land tenure security, forestlands access and benefit-sharing dynamics which put the local communities at a more significant disadvantage (Lund et al., 2012; Dumenu et al., 2014; Arhin, 2015; Forestry Commission, 2015; Hajjar, 2015; Ramcilovic-Suominen \& Epstein, 2015; Mensah et al., 2017; O'Sullivan et al., 2018; Kansanga \& Luginaah, 2019). For example, a study by (Kansanga \& Luginaah, 2019) in the Kintampo-Boamoa forest district and Offinso forest district revealed how migrant farmers and local community people had been affected by the activities of Mere Plantations Limited, a private company operating in those areas. In the study, a 51-year-old migrant farmer narrated how he was ejected from a land he had been farming and growing food crops for over 15 years under the state-led MTS. According to him, Mere Plantations Limited, which had the forest's concession, asked him and others to stop farming on the land. The company quickly cleared the and started their forest plantations. What worried him the most was that many of the forests lie idle after several years of acquiring the concession (Kansanga \& 
Luginaah, 2019). The same study found how stressful and difficult it was for the displaced farmers to access some degraded forest for temporal farming activities unless they pass through influential persons and financial inducements. They claimed that fertile portions of the forest under these plantation companies could be rented for about 1500 Ghana Cedis [about 350 USD] per hectare. "When the forest was allocated to plantation companies, they banned us from farming", "Since then I have moved my farm from one hideout to another through the seasons" (Kansanga \& Luginaah, 2019). The hideout farms are illegal farming that the Forestry Commission task force destroy, which demotivates the farmers to invest adequately in the food and cash crops farms. Sadly, the ejected and displaced farmers were not compensated by the company. The above experiences are indications that the private investors in carbon forestry are often motivated by economic incentives rather than local community needs and aspirations (Kansanga \& Luginaah, 2019). Because the governments' primary objective as far as the national reforestation programmes is concerned are to ensure the restoration of the degraded lands and forests for carbon mitigation purposes (Andoh \& Lee, 2018). Ghana's REDD+ implementation activities have been denying local farmers' access to degraded forestlands, where they had lived and worked over the years (Kansanga \& Luginaah, 2019).

Relatedly, a study carried in 39 timber-producing communities in the BrongAhafo and Western regions of Ghana revealed that the timber companies do not sign the Social Responsibility Agreements [SRAs] that grant communities a 5\% stumpage fee that accrues from timber revenue as part of their share of the management of forest resources (Tropenbos International, 2017). Likewise, some timber-producing communities lack information regarding the $5 \%$ stumpage fee they are entitled to receive from timber companies (Agyei \& Adjei, 2017). Therefore, it is unclear whether the timber-producing communities get their fair share from the SRAs (Agyei \& Adjei, 2017). Thus, the non-observance of the SRAs negotiations make the communities dissatisfied as they see the lack of accountability and transparency shrouded in the SRAs that timber companies sign with the communities (Agyei \& Adjei, 2017). The illegal chainsaw operations occurring in both off-reserve and on-reserve forests have been attributed to the lack of lumber supply for domestic use (Tropenbos International, 2017). Thus, the timber companies who possess the degraded off-reserve and on-reserve forests as their concessions only target foreign export of timber other than the local market supply (Tropenbos International, 2017). Thus, depriving the local people of access to lumber for domestic use.

Hence the artisanal millers who need lumber for their domestic activities and market use illegal chainsaw operators as their sources of lumber for domestic use and supply (Agyei \& Adjei, 2017). For instance, a nationwide survey carried out by Tropenbos International in 2017 revealed that $35 \%$ out of 221 artisanal millers in Ghana still depend on illegal timber for their domestic operations (Tropenbos International, 2017). Although farmers cannot legally harvest natu- 
rally occurring trees in the farms, they are entitled to compensation should the timber harvesting activities cause crops destruction (Boakye, 2018). Nevertheless, the contention is that there is no standardised compensation payment to the affected farmer whose crops get destroyed during logging operations (Ministry of Lands and Natural Resources, 2016). Accordingly, the laxity in enforcing compensation payment is a bane to achieving sustainable forestry strategies.

Similarly, tenant farmers' permission is not obtained when timber companies harvest the naturally occurring trees they had tendered and nurtured to maturity, and in most cases, compensations are not paid for damaged cash and food crops (Ministry of Lands and Natural Resources, 2016). Even where compensations paid to farmers, they are associated with delays and several cumbersome procedures and processes that recipient farmers had to go through. The MTS intervention is supposed to refurbish degraded forests and establish new plantation to meet the timber production needs, enhanced carbon stock and general ecosystem development. However, the MTS intervention forbids farmers to intercrop cassava, an important staple food in Ghana, at the early stages of the plantation (Insaidoo et al., 2012; Acheampong et al., 2016), thus creating a disincentive to farmers who want early food security and money from cassava consumption and sale (Acheampong et al., 2016). The MTS officials claim that intercropping cassava will create shade and prevent adequate sunlight for the planted tree seedlings, and the cassava will compete for the required nutrients for the plants to grow quickly (Acheampong et al., 2016). However, intercropping cassava with the trees could boost the participating farmers' food security needs and provide them income when they sell the cassava. Cassava takes less than a year to be matured for harvesting. Also, the MTS farmers feel insecure due to the absence of farmers' inventory and records on planting, maintenance, and benefit-sharing plans, making them lack full commitment to maintain the trees under the MTS project (Acheampong et al., 2016). The benefit-sharing arrangement under the MTS is supposed to be $40 \%$ timber revenue going to the Forestry Commission, $40 \%$ to the farmers, $15 \%$ to traditional landowners and $5 \%$ to forest-fringe communities (Acheampong et al., 2016).

Interventions that reduce forest to only carbon mitigation tool rather than focusing on multi-purpose functions and services of the forest will make local forest communities vulnerable since they depend on forest ESs for livelihood and wellbeing (Ojha et al., 2019). Broadly, Ghana's carbon plantation development activities ignore the heterogenous assessment and analysis of the local forest communities affected by the plantation projects (Narh, 2019) and design appropriate livelihood interventions to enhance their wellbeing. Thus, the government of Ghana's interest in REDD+ focuses on the monetary and financial benefits rather than addressing equity issues, policy gaps and loopholes, and other practical weaknesses (Saeed et al., 2018). The non-addressing of land and tree tenure security, benefit-sharing, rights and access to degraded forestlands hamper the forest-dependent people and communities to meet the livelihood needs 
and aspiration. The study highlights the underlying factors in Ghana's forest policy interventions, causing perceived injustices that lead to forest resources degradation and loss. We argue that until the underlying problems governance faces in addressing forest degradation, such as socio-economic issues, policy and institutional weaknesses and failures are adequately dealt with, direct forest governance challenges such as illegal logging, illegal mining, bad farming practices, and expansion of cocoa plantations in the forests will persist. This review is aimed at highlighting the inherent injustices such as lack of appropriate benefit-sharing, lack of tree tenure and access to degraded forest lands for farming and a high focus on carbon forestry in Ghana's forest policies and intervention which are detrimental to local forest communities. These factors directly or indirectly drive deforestation and forest degradation in Ghana's HFZs. The review is structured, to begin with, the introduction, followed by methods, trends of forest policies in Ghana, injustices in forest policy interventions, effects of imbalanced benefits of forest policy interventions and lessons for achieving win-win forest co-benefits and conclusion.

\section{Methods}

The study employs a desktop literature search of numerous web-based databases using the keywords, as illustrated in Figure 2. The web-based databases involved in the search include Google Scholar, Scopus, and Science Direct. The search was based explicitly on Ghana's forest policy interventions which are expected to produce co-benefits from forest benefits/resources. Key terms employed in the search processes were "Forest policy interventions" OR "Ghana" OR "Forest injustices" OR "Forest resources" OR "Climate mitigation". Consequently, the keywords were combined with expanding search, which yielded other words for the study. While our search was intended to capture an extensive range of studies that would offer an adequate understanding of the injustices in forest policy interventions in Ghana, we limited our search results from 2008 to 2020 for the scientific publications based on Ghana's forest policy interventions. This is because most forest policy interventions that sought to promote safeguards and access to forest resources to forest-dependent communities occurred within these periods. The rationale for limiting our search data from 2008 to 2020 was to focus on the current forest policy interventions containing injustices. However, other forest policy documents obtained did not follow any prescribed date.

\begin{tabular}{|c|c|c|c|c|}
\hline Search Engine & & bine & rch Words & Search Output \\
\hline $\begin{array}{c}\text { Google } \\
\text { Scholar } \\
\text { Scupus } \\
\text { Science } \\
\text { Direct }\end{array}$ & $\begin{array}{l}\text { Forest policy } \\
\text { interventions } \\
\text { Ghana } \\
\text { Forest injustices } \\
\text { Forest resources } \\
\text { Climate mitigation }\end{array}$ & $\mathrm{OR}$ & $\begin{array}{l}\text { Forest resources } \\
\text { Lack of forest access } \\
\text { rights } \\
\text { Forest benefit-sharing } \\
\text { Tree tenure insecurity } \\
\text { Weak forest } \\
\text { policy/institutions }\end{array}$ & $\begin{array}{l}\text { Illegal logging } \\
\text { Illegal mining } \\
\text { Overexploitation of } \\
\text { forest resources } \\
\text { Deforestation } \\
\text { Forest degradation } \\
\text { Forest cover loss }\end{array}$ \\
\hline
\end{tabular}

Figure 2. Methodological processes for literature search using keywords in various web-based databases. 
Our initial screening of the various literature yielded over 110 papers. We further refined the results by removing those papers based on purely theoretical and conceptual contributions after reading the abstract. We then had the final papers of 45 based on empirical studies on forest issues that contain injustices such as lack/inadequate benefit-sharing, tree/land tenure, and forest access rights. The papers were peer-reviewed journal articles that focus on Ghana's forest policy interventions and other jurisdictions. Also, Ghana Forestry Commission and Food and Agriculture Organizations [FAO] documents were searched for the study. Furthermore, several policy intervention documents, forest technical reports, book chapters, government forest policy publications were reviewed to enrich the study.

\section{Trends in Key Forest Policies, Legislations and Interventions with Their Objectives in Ghana}

Before the colonial era and the state-led forest management and intervention, chiefs acted as the custodians of the community forests under their jurisdictions and in the people's trust (Owubah et al., 2001). The chiefs protected these forests through the customary law system, until 1927 when the Forest Ordinance was enacted, which demarcated stool lands into forest reserves. Since independence, successive governments maintained the top-down forest management approach where state agencies were charged with enacted forest laws, policies, and legislation with little or no community involvement (Kansanga \& Luginaah, 2019). Table 1 illustrates some of the key forest laws, policies, legislations and interventions and their major objectives developed and adopted to protect, conserve and manage Ghana's forests for multiple services, products and benefits. Although Ghana had developed a plethora of these forest policies and interventions since 1948 Forest Policy which created permanent forest estates, protection of forests, water catchment areas and protection of the environment for ecological balance, the 1994 Forest and wildlife Policy marks the beginning of modern forest governance policy that recognised community forestry and forest conservation. However, none of these captured policies and interventions explicitly mention forest benefits to forest-fringe communities. Even the integrated community forest management schemes have not yielded the desired benefit-sharing, tree tenure security and timber access rights to forest-fringe communities (Kansanga \& Luginaah, 2019).

\section{Injustices in Forest Policy/Interventions}

Although almost all the current forest policy interventions highlighted above emphasise forest protection and conservation, they hardly incorporate strategies to promote sustainable benefit flows from forest to local forest-dependent communities. In Ghana, forest policymakers and planners focus more on forest carbon mitigation activities than other forest functions that directly benefit the local forest-dependent communities. This is because almost all of Ghana's HFZs are 
Table 1. Key forest policies, legislation and interventions in Ghana (1994-2012).

\begin{tabular}{|c|c|c|c|}
\hline $\begin{array}{l}\text { Forest policies, } \\
\text { legislation \& } \\
\text { interventions }\end{array}$ & Major objectives & $\begin{array}{l}\text { Forest policies, } \\
\text { legislation \& } \\
\text { interventions }\end{array}$ & Major objectives \\
\hline $\begin{array}{l}1994 \text { Forest and } \\
\text { Wildlife Policy }\end{array}$ & $\begin{array}{l}\text { - Protection of forests and species conservation } \\
\text { - Deregulation and streaming of bureaucratic controls } \\
\text { on wood export marketing } \\
\text { - Involvement community in the conservation of } \\
\text { forest and wildlife resources } \\
\text { - Regulation of timber harvesting } \\
\text { - Development of cottage and agro-based industry } \\
\text { - Community forestry and forest conservation } \\
\text { - Rehabilitation and development of degraded forests }\end{array}$ & $\begin{array}{l}\text { Timber Resources } \\
\text { Management } \\
\text { (Amendment) Act } \\
\text { of } 2002\end{array}$ & $\begin{array}{l}\text { - Timber utilization contract } \\
\text { - Offences for illegal logging } \\
\text { - Protection of logging on farms and } \\
\text { plantations } \\
\text { - Community forestry and forest } \\
\text { conservation } \\
\text { - Protect land with farms from logging } \\
\text { - Protection private forest plantation } \\
\text { - } \text { Duration of timber concession rights }\end{array}$ \\
\hline $\begin{array}{l}\text { Timber Resource } \\
\text { Management Act, } \\
1997 \text { - Act } 547\end{array}$ & $\begin{array}{l}\text { - Timber utilization contract } \\
\text { - Offences for illegal logging } \\
\text { - Protection of logging on farms and plantations }\end{array}$ & $\begin{array}{l}\text { Modified Taungya } \\
\text { Scheme (MTS) } \\
(2002)\end{array}$ & $\begin{array}{l}\text { Engage in tree planting and nurturing } \\
\text { in degraded forest lands } \\
\text { - Growing food and cash crops along the } \\
\text { trees to provide income and } \\
\text { employment }\end{array}$ \\
\hline $\begin{array}{l}\text { Community Resources } \\
\text { Management Areas } \\
\text { (CREMAs) (2000) }\end{array}$ & $\begin{array}{l}\text { - Reduced deforestation and forest degradation } \\
\text { - Promote sustainable farming practices } \\
\text { - To curtail illegal logging } \\
\text { - Enhance conservation and management of protected } \\
\text { areas and forest reserves }\end{array}$ & $\begin{array}{l}\text { VPA EU (FLEGT) } \\
(2007)\end{array}$ & $\begin{array}{l}\text { - Address illegal logging } \\
\text { - Improve forest governance } \\
\text { - Promote trade in legal timber products }\end{array}$ \\
\hline $\begin{array}{l}\text { National Forest } \\
\text { Plantation } \\
\text { Development } \\
\text { Programme (2001) }\end{array}$ & $\begin{array}{l}\text { - Accelerate national forest plantation by private, } \\
\text { government and local communities } \\
\text { - Restoration of degraded forestlands } \\
\text { - Increased forest cover } \\
\text { - Increased wood supply to domestic use \& market }\end{array}$ & $\begin{array}{l}\text { Ghana REDD+ } \\
(2008)\end{array}$ & $\begin{array}{l}\text { - Reduce emission from deforestation } \\
\text { and forest degradation } \\
\text { - Sustainable forest management } \\
\text { - Conservation of forest biodiversity } \\
\text { - Enhancement of carbon stocks }\end{array}$ \\
\hline $\begin{array}{l}\text { The Forest Protection } \\
\text { Amendment Act } 2002\end{array}$ & $\begin{array}{l}\text { - Community forestry and forest conservation } \\
\text { - Protect forest and wildlife } \\
\text { - Reforestation and afforestation programmes } \\
\text { - Forest offences penalties } \\
\text { - Protection of water catchment areas }\end{array}$ & $\begin{array}{l}\text { Forest and } \\
\text { Wildlife Policy } \\
2012\end{array}$ & $\begin{array}{l}\text { - Laws, institutions, systems \& } \\
\text { organizations to promote sustainable } \\
\text { management and conservation of forest } \\
\text { landscapes and wildlife }\end{array}$ \\
\hline
\end{tabular}

earmarked for REDD+ carbon mitigation purposes. For instance, the private investors who engage in carbon forestry activities in Ghana under the REDD+ strategies tend to be motivated solely by economic benefits and incentives and do not take the local people and landowners' livelihoods into account (Kansanga \& Luginaah, 2019). The private forest investors in carbon forestry plantation projects regard themselves as emerging forest developers who often deny local Ghanaian farmers access to farm on degraded forestlands even though these local farmers cultivate these lands through state-led forest management (Kansanga \& Luginaah, 2019). Even where SRAs are signed between the private carbon forest plantation investors, the communities only receive a small fraction of the stumpage fee. The forest beneficiary communities find a 50\% stumpage fee from timber revenue giving to the Forestry Commission and the communities receiving only $5 \%$ share in the form SRAs as unfair because they are the ones who 
cared and nurtured trees till maturity (Ministry of Lands and Natural Resources, 2016; Agyei \& Adjei, 2017; Tropenbos International, 2017). The existing forest policies and laws are the major factors that impede equitable benefit-sharing under the REDD+ regime at the community level (Saeed et al., 2018). REDD+ mechanism, expected to generate co-benefits for livelihoods enhancement, poverty alleviation, conservation of biodiversity and carbon benefit, is faced with benefit-sharing and tree tenure challenges (Forestry Commission, 2015). In Ghana, women, the poor forest people, and the youth are considered vulnerable; hence, they cannot participate even in the Voluntary Partnership Agreements [VPA] and REDD+ forest governance initiatives and activities (Satyal, 2018). Even though women, for example, are mostly those who engage in daily food crops production, they hardly get the opportunity to express their views and concerns in forest policy intervention under the REDD+ mechanism (Satyal, 2018). The community forestry that is expected to generate the dual purpose of planting and nurturing trees and food and cash crops cultivation have tilted towards tree plantation. This is because the community forestry has less success story to tell as the concept is not popular in Ghana (Hajjar, 2015). Under the forest plantations and restoration interventions, the state allocates degraded reserves to private companies and entities where the revenues accruing from the plantations are distributed among beneficiaries as follows: private company $90 \%$, landowner 6\%, Forestry Commission 2\% and local community 2\% (Ministry of Lands and Natural Resources, 2016). The farmers and forest communities regard the existing benefit-sharing mechanism where private investors get $90 \%$ from forest plantation and only $2 \%$ and $6 \%$ to the communities and the landowners respectfully as unfair. They further claim that they do not benefit from naturally occurring trees they nurture on their farms (Insaidoo et al., 2012). Hence, the local forest communities see the current forest policies as having lapses in benefit-sharing, timber/tree tenure and ownership rights (Ramcilovic-Suominen \& Epstein, 2015). They argue that even where these benefit-sharing and timber/tree tenure exists, the communities and the farmers obtain only a minimal share of the benefits (Ramcilovic-Suominen \& Epstein, 2015). Accessing these meagre benefits also entails complex bureaucratic processes coupled with a lack of clarity on how timber revenue could be claimed by landowners and communities (Kansanga \& Luginaah, 2019). In particular, many farmers regard the existing tree tenure and benefit-sharing arrangements as unjust and discriminatory, making them developing apathetic attitudes towards tree growing and nurturing till maturity (Ramcilovic-Suominen \& Epstein, 2015). While the carbon forestry companies argue that they promote land and tree tenure security to benefit landless smallholder farmers, these farmers often counterclaim that the current arrangement often denies them access to farm on the degraded forests the companies had acquired as their concessions (Kansanga \& Luginaah, 2019). Some ejected farmers claim that private companies acquire degraded on-reserve and off-reserve forests in the name of carbon forest plantation and later rent the 
lands to their favourite farmers for crop farming under a dubious arrangement (Kansanga \& Luginaah, 2019). In this case, the displaced farmers become landless and vulnerable as they cannot acquire land for farming purposes (Kansanga \& Luginaah, 2019). Even in certain reserves such as the Ankasa forest reserve, harvesting of NTFPs is prohibited by law (Tilahun et al., 2016). Therefore, some farmers and local forest communities' inability to access land for farming has culminated in illegal encroachment and illegal farming in the forest reserves for food/cash crop farming. Also, the lack of appropriate tree tenure has caused illegal logging in the HFZs, driving forest resources degradation and loss in the Ghanaian forest landscapes.

\section{Effects of Imbalanced Benefits of Forest Policy Interventions}

The inability to access degraded forestland by forest-dependent communities for farming directly affects food security in the country (Ahmed et al., 2016). The landless smallholder farmers cannot access off-forest and on-reserves, resulting in illegal encroachment on the forest reserves and rehabilitated plantations, where they engage in "illegal farms" (Kansanga \& Luginaah, 2019). However, these illegal farms' sustainability is questionable as the GFC task force could destroy the farms at any time without compensation. Currently, virtually all offreserve forests in Ghana have been given out as private individual concessions for carbon forest plantation (Benefoh et al., 2018). The lack of timber harvesting rights by local community people and the bureaucratic processes involving the application for timber harvesting for domestic and household needs have culminated in widespread illegal logging in many off-reserve and on-reserve forests (e.g. See, Lund et al., 2012; Oduro et al., 2015; TBI, 2017). However, while the rate of deforestation may decline, forest degradation, on the other hand, may persist as the demand and supply for timber gap continue to widen in Ghana (Oduro et al., 2015). The non-addressing of the appropriate forest benefit-sharing, access to timber for local use have bred forests illegalities and corruption, paving the way for illegal logging and mining, illegal farming in the forest reserves (Kansanga \& Luginaah, 2019; Teye, 2013). Many studies have confirmed that forest illegal activities such as illegal logging, illegal mining, illegal farming and forest fires constitute the major direct causes of deforestation and forest degradation [D\&FD] in Ghana (Derkyi et al., 2013; Fagariba et al., 2018; Obodai et al., 2019; Owusu \& Essandoh-Yeddu, 2018). Generally, many farmers' socio-economic needs in forest-fringe communities depend on both food and cash crops farming; hence, forest policy's inability to address this gap by making degraded lands accessible to them would further drive massive deforestation and forest degradation (O’Sullivan et al., 2018; Benefoh et al., 2018; Kansanga \& Luginaah, 2019). For instance, many farmers in forest-fringe communities lack alternative livelihood options and off-farm employment; hence their main income, employment and food security depend on food and cash crops farming (Oduro 
et al., 2015). The constant demand for forestlands for agricultural production put much pressure on both on-reserve and off-reserve forests. Due to migration into forest-fringe communities, the increased rural population puts immense pressure on scarce land, causing severe degradation in the natural environment (Baffoe \& Matsuda, 2018). Hence forest policy should also seek to provide alternative livelihoods options. Forest policy and governance interventions have also failed to adequately forge active community partnerships and smallholder farmer participation required to achieve win-win community benefits and sustainable forest resources use (Hajjar, 2015). This attests to the persistent violations of the forest rules exacerbating forest illegalities that have almost received social acceptance in many forest communities (Boakye, 2018; Hirons, 2015). For example, illegal logging is regarded as a job creation avenue and the means to survive the teeming unemployed youth, most of whom are school drop-outs (Boakye, 2018). Illegal logging involves the chain of activities ranging from the actual loggers, people who carry the lumber to the loading points [loading boys], those who load the lumber into the trucks and the vendors who cut the lumber into specific customer needs (Boakye, 2018). Therefore, there is the need for urgent actions and interventions in policy to assess holistically the dynamics of the perceived forest injustices that drive Ghana's forest resources degradation and near loss. Figure 3 shows forest injustices driving forest illegalities that cause deforestation and forest degradation in Ghana's HFZs and other forest landscapes. For instance, reducing deforestation and forest degradation requires tackling the underlying drivers such as benefit-sharing, land/tree tenure rights/ security that cause indirectly cause many forest illegalities.

\section{Lessons for Achieving Win-Win Forest Co-Benefits}

The analysis so far has indicated that Ghana's forest policy interventions are diverse with multifaceted dynamics. Viewing forest as a social-ecological system [SES] could help understand existing and potential problems, key issues, and dynamics and interactions within the forest landscapes (Melnykovych et al., 2018).

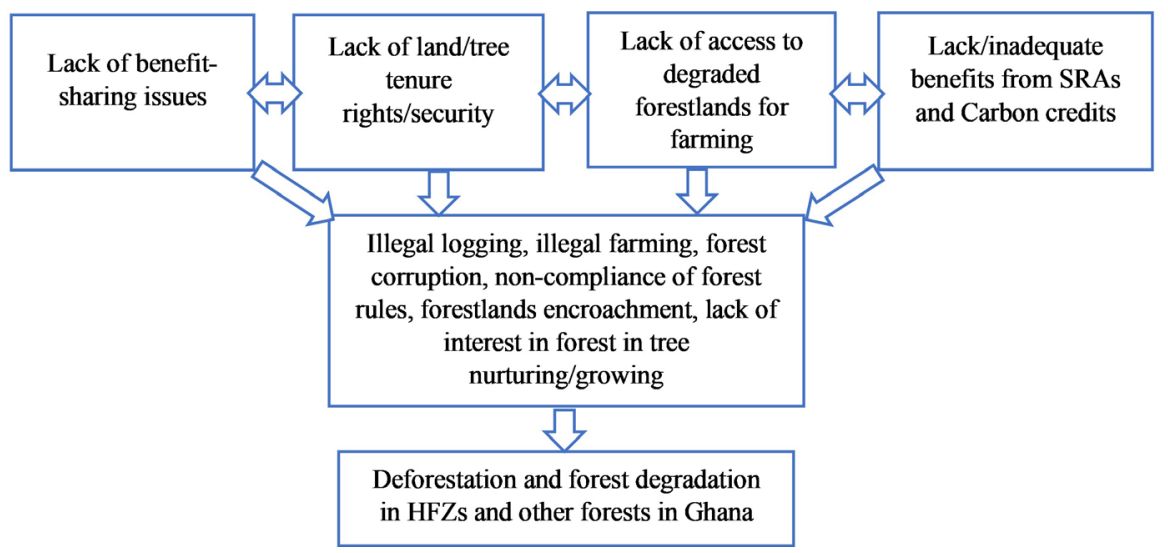

Figure 3. Forest injustices as drivers of forest illegalities leading to deforestation and forest degradation. 
The SES involves integrating social and ecological components to analyse and assess their intricate dynamics (Anderies et al., 2004). Since biodiversity conservation and forest carbon storage are mutually related (Newton et al., 2016) planners, and policymakers should endeavour to formulate and implement diverse approaches to increasing forest co-benefits in order to reduce D \& FD as well as increasing afforestation and reforestation schemes (Wilson et al., 2017). We propose the following as a way forward to reduce forest injustices to promote equitable forest co-benefits to reduce forests resources degradation, depletion and loss in Ghana.

\subsection{Increased Agroforestry Schemes}

The agroforestry systems practice could serve a win-win situation by increasing farmers' food and cash crops production while nurturing planted trees under the carbon forest plantation (den Besten et al., 2019). The state should negotiate with the private forest carbon investors to allow ejected and displaced farmers to continue to grow food and non-tree cash crops in the degraded forest concessions because the current carbon forest plantation projects fail to promote adequate incentives through benefit-sharing to enable communities to benefit from food and cash crop production. While at the same time, the trees sequester carbon for mitigation purposes. Also, Ghana's traditional agroforestry systems should be fully utilised to promote long-term forest ecosystem sustainability, to adequately utilise ESs and enhance short-term food security, job creation and income provision, and carbon mitigation (Akamani \& Hall, 2019). There must be an urgent need to address key governance gaps regarding tree/land tenure, carbon rights, conflicts/dispute resolution, forest reforms in all the carbon forest plantation projects and other forest landscapes (Dumenu et al., 2014).

\subsection{Provision of Alternative Livelihood Options}

Lack of alternative livelihoods leads to high dependence on forests (Addai \& Baidoo, 2013; Mensah \& Amoah, 2013; Melnykovych et al., 2018; Derkyi et al., 2013). Hence forest policy planners, spatial planners and decision-makers should endeavour to provide alternative livelihoods for forest-dwelling communities to reduce dependence on forest resources use (Peprah et al., 2017). Generally, rural livelihood activities, including agricultural activities, are significant causes of deforestation and forest/biodiversity degradation (Melnykovych et al., 2018; Ayivor \& Ekpe, 2012). As a result, forest policy needs to critically assess the interplay between forests and other sectors that can provide potential alternative sources of livelihoods for forest-dependent communities using the win-win strategy (Saeed et al., 2018). Alternatively, the state should endeavour to return forestlands to communities to manage (Kansanga \& Luginaah, 2019) in this way; they will have access to degraded forest lands for livelihoods purposes. Also, there should be social safeguard mechanisms for forest-fringe communities as the existing laws do not provide alternative livelihoods to the forest communities 
(Derkyi et al., 2013). Likewise, promoting property rights and making carbon a visible resource commodity could serve as alternative sources of income for forest-fringe communities (Asiyanbi et al., 2017).

\subsection{Increased Community Participation in Forest Governance}

Ineffective community participation in forest governance issues prevents forestdwelling communities' views into forest policy intervention planning. Community involvement is critical for the sustainable management of forests and land resources use. Active community participation in tree planting and forest conservation activities is required to enhance carbon forest plantation and livelihoods improvement (Peprah et al., 2017; O’Sullivan et al., 2018). However even where participation occurs, it only occurs at the implementation stages rather than policy/spatial planning, formulation and negotiation stages (Akamani et al., 2015). Improving involvement and participation in forest resources management can enhance transparency \& accountability in benefits accruing from Social Responsibility Agreements [SRA] signed between private carbon forestry investors and local communities (Agyei \& Adjei, 2017). Forest-fringe communities' involvement is critical during the planning, designing, and drafting of forest policies as the outcomes of these policies affect them culturally, socially, economically, and politically. Active involvement and participation in forest planning, management and governance processes can promote sustainability, build local trust and generate confidence, sustain and build the capacity of forestfringe communities in forest governance issues (Baruah et al., 2016). Forest laws and policy reforms are critically needed to promote effective institutional coordination, increased accountability and transparency, and address the crucial issues that impede land/tree tenure security and provide appropriate benefitsharing mechanisms to manage forest resources sustainably (e.g. see Lund et al., 2012; Akamani et al., 2015; Oduro et al., 2015; Hajjar, 2015; Agyei \& Adjei, 2017, Asiyanbi et al., 2017; Bukari \& Kuusaana, 2018; Fagariba et al., 2018; Satyal, 2018; Kansanga \& Luginaah, 2019; Hansen et al., 2015).

\subsection{Focus Policies to Deal with the Underlying Causes of High-Forest Dependence}

Forest policy actors should critically assess the underlying factors such as the local forest actors and stakeholders' poverty dynamics as they can constitute the key mediating drivers of forest illegalities. For instance, many forest-fringe communities regard illegal chainsaw operations as their livelihood option for income supplement and employment (Boakye, 2018). The factors that indirectly drive forest-fringe communities to engage in activities that degrade forests include weak forest institutions and lack of coordination (Akamani et al., 2015), and institutional lapses and failures of forest-related institutions (Agyei \& Adjei, 2017). For instance, the lack of forest policy enforcement and monitoring had culminated in ubiquitous non-compliance of forest rules, leading to all forms of 
forest illegalities (Ramcilovic-Suominen \& Epstein, 2015). Forest policies, interventions, managers and planners often focus on curbing D\&FD via curtailing illegal logging, illegal farming and illegal mining, among others, instead of critically and comprehensively analysing and assessing the underlying drivers that propel the direct drivers. Forest governance structures are characterised with major flaws which serve as underlying drivers of Ghana's forest/biodiversity degradation and loss (Benefoh et al., 2018). Until these underlying dynamics are adequately analysed and assessed, D\&FD would continue as the forest-dependent communities must find ways and means to meet livelihood and survival needs through engaging in forest illegalities.

\subsection{Focus on Forest Governance from the Social-Ecological Perspective}

Using social-ecological networks that link community-led approaches to managing forest resources can address the pervasive ecological concerns at the local levels, such as D\&FD and increased forest resources access (Lesniewska \& McDermott, 2014; Falk et al., 2018). Notably, reducing D\&FD coupled with increased afforestation through the agroforestry schemes can serve the win-win carbon stocks enhancement and improved NTFPs for forest-dependent communities. For example, the ineffective community rights to access forests and forest resources are underlying drivers militating against the realisation of the European Union Forest Law and Environmental Governance and Trade [EU FLEGT] goal of sustainable forests resources governance (Lesniewska \& McDermott, 2014). Tree and land tenure reforms must carefully be tailored to suit the local conditions and dynamics to ensure equity for the poor majority and the marginalised population with gender considerations (Hajjar, 2015). There is a need to improve distributive equity, improve stakeholder's knowledge and capacity, and assess the historical contextual issues regarding equity and forest resources ownership (Saeed et al., 2018).

\section{Conclusion}

This review dealt with the fundamental dynamics underlying Ghana's forest policy interventions. Based on the historical forest policy trends developed and implemented in Ghana, it argues for the case that forest policy interventions have most often than not focused and favoured enhanced carbon stock and sequestration potentials in Ghana's forests compared to a provision of rights and access to forestland and resources by forest-dependent people and communities. The findings show that the inability of forest-dependent communities to secure the tree and land ownership and tenure rights and access culminated into all forms of forest illegalities, including illegal chainsaw logging and illegal mining, to mention a few that have been occurring in the HFZs and the reserves leading to forest resources degradation and loss in Ghana. Based on these findings, we propose lessons to serve as a blueprint for forest policy planners and managers 
to plan for win-win enhanced carbon stocks and provision of forest benefits to forest-dependent communities to promote sustainable forest resources in all Ghana's forests. The paper argues that forest planners and managers need to plan, analyse and assess the multiple functions of forest ESs from the socialecological perspective in order to ensure active and diverse interaction and inclusion of the communities, private sector, non-governmental organisations [NGOs], civil society and other relevant actors and institutions in the forest governance processes. Additionally, adopting an integrated social-ecological approach in forest landscape ESs can assist in the planning, designing, implementing and evaluating to achieve the sustainable provision of NTFPs to benefit forest-dependent communities while enhancing forest carbon stocks and sequestration potentials to mitigate greenhouse gases emission. The key underlying factors that propel direct causes of injustices in access to forestland and resources by forest-dependent communities must be given adequate priority to curtail the forest illegalities. Finally, because forest-dependent people and communities have their livelihoods and survival needs tied to the forests, all efforts must be made to achieve forests resources management, livelihood enhancement and governance sustainability.

\section{Funding}

The received support from the Czech ministry of education LM2018123-CzeCOS and the Slovak Science Foundation VEGA 2/0013/17 for publication.

\section{Acknowledgements}

We are most grateful for the support received from the project of the Czech ministry of education LM2018123-CzeCOS and the Slovak Science Foundation VEGA 2/0013/17 for the production of this review article.

\section{Conflicts of Interest}

The authors declare no conflicts of interest regarding the publication of this paper.

\section{References}

Acheampong, E., Insaidoo, T. F., \& Ros-Tonen, M. A. (2016). Management of Ghana's Modified Taungya System: Challenges and Strategies for Improvement. Agroforestry Systems, 90, 659-674. https://doi.org/10.1007/s10457-016-9946-7

Acheampong, E. O., Sayer, J., \& Macgregor, C. J. (2018). Road Improvement Enhances Smallholder Productivity and Reduces Forest Encroachment in Ghana. Environmental Science \& Policy, 85, 64-71. https://doi.org/10.1016/j.envsci.2018.04.001

Before Addai. It replaces Ahenken \& Boon, 2010) in the introduction

Addai, G., \& Baidoo, P. K. (2013). The Effects of Forest Destruction on the Abundance, Species Richness and Diversity of Butterflies in the Bosomkese Forest Reserve, Brong Ahafo Region, Ghana. Journal of Applied Biosciences, 64, 4763-4772. https://doi.org/10.4314/jab.v64i1.88465 
Agyei, F. K., \& Adjei, P. O. W. (2017). Representation without Accountability in Forestry: Experiences from the Social Responsibility Agreement in Ghana. Forest Policy and Economics, 80, 34-43. https://doi.org/10.1016/j.forpol.2017.03.003

Ahenkan, A., \& Boon, E. (2010). Assessing the Impact of Forest Policies and Strategies on Promoting the Development of Non-Timber Forest Products in Ghana. Journal of Biodiversity, 1, 85-102. https://doi.org/10.1080/09766901.2010.11884720

Ahmed, A., Lawson, E. T., Mensah, A., Gordon, C., \& Padgham, J. (2016). Adaptation to Climate Change or Non-Climatic Stressors in Semi-Arid Regions? Evidence of Gender Differentiation in Three Agrarian Districts of Ghana. Environmental Development, 20, 45-58. https://doi.org/10.1016/j.envdev.2016.08.002

Akamani, K., \& Hall, T. E. (2019). Scale and Co-Management Outcomes: Assessing the Impact of Collaborative Forest Management on Community and Household Resilience in Ghana. Heliyon, 5, e01125. https://doi.org/10.1016/j.heliyon.2019.e01125

Akamani, K., Wilson, P. I., \& Hall, T. E. (2015). Barriers to Collaborative Forest Management and Implications for Building the Resilience of Forest-Dependent Communities in the Ashanti Region of Ghana. Journal of Environmental Management, 151, 1121. https://doi.org/10.1016/j.jenvman.2014.12.006

Anderies, J. M., Janssen, M. A., \& Ostrom, E. (2004). A Framework to Analyze the Robustness of Social-Ecological Systems from an Institutional Perspective. Ecology and Society, 9, 18. https://doi.org/10.5751/ES-00610-090118

Andoh, J., \& Lee, Y. (2018). Forest Transition through Reforestation Policy Integration: A Comparative Study between Ghana and the Republic of Korea. Forest Policy and Economics, 90, 12-21. https://doi.org/10.1016/j.forpol.2018.01.009

Arhin, A. A. (2015). Halting Deforestation to Advance Sustainable Development: Progress, Prospects and Challenges of REDD+ Readiness in Ghana. In D. Reyes (Ed.), Sustainable Development: Processes, Challenges and Prospects (pp. 39-64). Hauppauge, NY: Nova Publishers.

Asiyanbi, A. P., Arhin, A. A., \& Isyaku, U. (2017). REDD+ in West Africa: Politics of Design and Implementation in Ghana and Nigeria. Forests, $8,78$. https://doi.org/10.3390/f8030078

Ayivor, J. S., \& Ekpe, E. (2012). Community-Based Integrated Natural Resource Management in Okyeman Traditional Area of the Eastern Region, Ghana: Socio-Economic Profile of the Okyeman Traditional Area. West African Journal of Applied Ecology, 20, $35-45$.

Baffoe, G., \& Matsuda, H. (2018). A Perception Based Estimation of the Ecological Impacts of Livelihood Activities: The Case of Rural Ghana. Ecological Indicators, 93, 424-433. https://doi.org/10.1016/j.ecolind.2018.04.074

Baruah, M., Bobtoya, S., Mbile, P., \& Walters, G. (2016). Governance of Restoration and Institutions: Working with Ghana's Community Resource Management Areas. World Development Perspectives, 3, 38-41. https://doi.org/10.1016/j.wdp.2016.11.008

Benefoh, D. T., Villamor, G. B., van Noordwijk, M., Borgemeister, C., Asante, W. A., \& Asubonteng, K. O. (2018). Assessing Land-Use Typologies and Change Intensities in a Structurally Complex Ghanaian Cocoa Landscape. Applied Geography, 99, 109-119. https://doi.org/10.1016/j.apgeog.2018.07.027

Boakye, J. (2018). Understanding Motivations for Violation of Timber Harvesting Regulation: The Case of Chainsaw Operators in Ghana. Forest Policy and Economics, 87, 85-92. https://doi.org/10.1016/j.forpol.2017.10.020

Boon, E., \& Ahenkan, A. (2012). Assessing Climate Change Impacts on Ecosystem Services and Livelihoods in Ghana: Case Study of Communities around Sui Forest Re- 
serve. Journal of Ecosystem \& Ecography, S3, 001. https://doi.org/10.4172/2157-7625.S3-001

Bukari, K. N., \& Kuusaana, E. D. (2018). Impacts of Large-Scale Land Holdings on Fulani Pastoralists' in the Agogo Traditional Area of Ghana. Land Use Policy, 79, 748-758. https://doi.org/10.1016/j.landusepol.2018.09.018

den Besten, J. W., Arts, B., \& Behagel, J. (2019). Spiders in the Web: Understanding the Evolution of REDD+ in Southwest Ghana. Forests, 10, 117. https://doi.org/10.3390/f10020117

Derkyi, M., Ros-Tonen, M. A., Kyereh, B., \& Dietz, T. (2013). Emerging Forest Regimes and Livelihoods in the Tano Offin Forest Reserve, Ghana: Implications for Social Safeguards. Forest Policy and Economics, 32, 49-56. https://doi.org/10.1016/j.forpol.2013.03.005

Dumenu, W. K., Samar, S., Mensah, J. K., Derkyi, M., Oduro, K. A., Pentsil, S. et al. (2014). Benefit Sharing Mechanism for REDD+ Implementation in Ghana (pp. 1-58). Consultancy Report, Accra, Ghana: Forestry Commission.

Fagariba, C. J., Song, S., \& Soule, S. K. (2018). Livelihood Economic Activities Causing Deforestation in Northern Ghana: Evidence of Sissala West District. Open Journal of Ecology, 8, 57-74. https://doi.org/10.4236/oje.2018.81005

Falk, T., Spangenberg, J. H., Siegmund-Schultze, M., Kobbe, S., Feike, T. et al. (2018). Identifying Governance Challenges in Ecosystem Services Management-Conceptual Considerations and Comparison of Global Forest Cases. Ecosystem Services, 32, 193-203. https://doi.org/10.1016/j.ecoser.2018.07.012

FAO (2018). The State of the World's Forests 2018-Forest Pathways to sustainable development. Rome.

Forestry Commission (2015). National REDD+Strategy. Report prepared by Prize Water House Coopers for the Forestry Commission of Ghana, Accra.

Forestry Commission (2016). Ghana REDD+ Strategy 2016-2035.

Forestry Commission (2019). Enhanced Land Use Land Cover Map of Ghana. https://www.myjoyonline.com

Führer, E. (2000). Forest Functions, Ecosystem Stability and Management. Forest Ecology and Management, 132, 29-38. https://doi.org/10.1016/S0378-1127(00)00377-7

Hajjar, R. (2015). Advancing Small-Scale Forestry under FLEGT and REDD in Ghana. Forest Policy and Economics, 58, 12-20. https://doi.org/10.1016/j.forpol.2014.09.014

Hansen, C. P., Pouliot, M., Marfo, E., Obiri, B. D., \& Treue, T. (2015). Forests, Timber and Rural Livelihoods: Implications for Social Safeguards in the Ghana-EU Voluntary Partnership Agreement. Small-Scale Forestry, 14, 401-422. https://doi.org/10.1007/s11842-015-9295-9

Hirons, M. (2015). Trees for Development? Articulating the Ambiguities of Power, Authority and Legitimacy in Governing Ghana's Mineral Rich Forests. The Extractive Industries and Society, 2, 491-499. https://doi.org/10.1016/j.exis.2015.05.001

Hurteau, M. D., North, M. P., Koch, G. W., \& Hungate, B. A. (2019). Opinion: Managing for Disturbance Stabilises Forest Carbon. Proceedings of the National Academy of Sciences of the United States of America, 116, 10193-10195. https://doi.org/10.1073/pnas.1905146116

Insaidoo, T. F., Ros-Tonen, M. A., Hoogenbosch, L., \& Acheampong, E. (2012). Addressing Forest Degradation and Timber Deficits: Reforestation Programmes in Ghana. ETFRN News, 53, 230-239.

Kansanga, M. M., \& Luginaah, I. (2019). Agrarian Livelihoods under Siege: Carbon Fore- 
stry, Tenure Constraints and the Rise of Capitalist Forest Enclosures in Ghana. World Development, 113, 131-142. https://doi.org/10.1016/j.worlddev.2018.09.002

Lesniewska, F., \& McDermott, C. L. (2014). FLEGT VPAs: Laying a Pathway to Sustainability via Legality Lessons from Ghana and Indonesia. Forest Policy and Economics, 48, 16-23. https://doi.org/10.1016/j.forpol.2014.01.005

Lund, J. F., Carlsen, K. I. R. S. T. E. N., Hansen, C. P., \& Treue, T. H. O. R. S. T. E. N. (2012). The Political Economy of Timber Governance in Ghana. ETFRN News, 53, 117-126.

Melnykovych, M., Nijnik, M., Soloviy, I., Nijnik, A., Sarkki, S., \& Bihun, Y. (2018). Social-Ecological Innovation in Remote Mountain Areas: Adaptive Responses of Forest-Dependent Communities to the Challenges of a Changing World. Science of the Total Environment, 613, 894-906. https://doi.org/10.1016/j.scitotenv.2017.07.065

Mensah, C. A., Antwi, K. B., Eshun, J. K., \& Baidoo, P. (2017). Towards Sustainability: Overcoming the Physical Barriers to Urban Green Spaces in Kumasi, Ghana. Ghana Journal of Geography, 9, 125-150.

Mensah, S. O., \& Amoah, S. T. (2013). Co-Managing Ecosystem Services of Forest Reserves in Ghana: The Case of the Bobiri Forest Reserve (BFR) in Kubease in the Ashanti Region of Ghana. Developing Country Studies, 3, 50-61.

Ministry of Lands and Natural Resources (2016) Tree Tenure \& Benefit Sharing Framework in Ghana.

Montesinos, D. (2019). Forest Ecological Intensification. Trends in Plant Science, 24, 484-486. https://doi.org/10.1016/j.tplants.2019.03.009

Narh, P. (2019). Sustainability Outcomes of Teak Plantation Development in Dormaa, Ghana. Environmental Development, 29, 44-54. https://doi.org/10.1016/j.envdev.2018.12.002

Newton, P., Oldekop, J. A., Brodnig, G., Karna, B. K., \& Agrawal, A. (2016). Carbon, Biodiversity, and Livelihoods in Forest Commons: Synergies, Trade-Offs, and Implications for REDD+. Environmental Research Letters, 11, Article ID: 044017. https://doi.org/10.1088/1748-9326/11/4/044017

O’Sullivan, R., Roth, M., Antwi, Y. A., Ramirez, P., \& Sommerville, M. (2018). Land and Tree Tenure Innovations for Financing Smallholder Cocoa Rehabilitation in Ghana. Presentation at the 2018 World Bank Conference on Land and Poverty, Washington DC, 19-23 March, 2018.

Obodai, J., Adjei, K. A., Odai, S. N., \& Lumor, M. (2019). Land Use/Land Cover Dynamics Using Landsat Data in a Gold Mining Basin-The Ankobra, Ghana. Remote Sensing Applications: Society and Environment, 13, 247-256. https://doi.org/10.1016/j.rsase.2018.10.007

Oduro, K. A., Mohren, G. M. J., Pena-Claros, M., Kyereh, B., \& Arts, B. (2015). Tracing Forest Resource Development in Ghana through Forest Transition Pathways. Land Use Policy, 48, 63-72. https://doi.org/10.1016/j.landusepol.2015.05.020

Ojha, H., Maraseni, T., Nightingale, A., \& Bhattarai, B. (2019). Rescuing Forests from the Carbon Trap. Forest Policy and Economics, 101, 15-18.

https://doi.org/10.1016/j.forpol.2019.01.007

Owubah, C. E., Le Master, D. C., Bowker, J. M., \& Lee, J. G. (2001). Forest Tenure Systems and Sustainable Forest Management: The Case of Ghana. Forest Ecology and Management, 149, 253-264.

Owusu, A. B., \& Essandoh-Yeddu, F (2018). Assessment of the Forest Cover Change in the Forest-Savannah Transitional Zone, Ghana between 1990-2013 Using Remote Sens- 
ing and GIS. Journal of Geomatics, 12, 89-100.

Pan, Y., Birdsey, R. A., Fang, J., Houghton, R., Kauppi, P. E., Kurz, W. A. et al. (2011). A Large and Persistent Carbon Sink in the World's Forests. Science, 333, 988-993. https://doi.org/10.1126/science.1201609

Peprah, P., Abalo, E. M., Amoako, J., Nyonyo, J., Duah, W. A., \& Adomako, I. (2017). "The Reality from the Myth": The Poor as Main Agents of Forest Degradation: Lessons from Ashanti Region, Ghana. Environmental \& Socio-Economic Studies, 5, 1-11.

Prip, C. (2018). The Convention on Biological Diversity as a Legal Framework for Safeguarding Ecosystem Services. Ecosystem Services, 29, 199-204.

https://doi.org/10.1016/j.ecoser.2017.02.015

Ramcilovic-Suominen, S., \& Epstein, G. (2015). The Impacts of Deterrence, Social Norms and Legitimacy on Forest Rule Compliance in Ghana. Forest Policy and Economics, 55, 10-20. https://doi.org/10.1016/j.forpol.2015.03.006

Saeed, A. R., McDermott, C., \& Boyd, E. (2018). Examining Equity in Ghana's National REDD+ Process. Forest Policy and Economics, 90, 48-58.

https://doi.org/10.1016/j.forpol.2018.01.006

Satyal, P. (2018). Civil Society Participation in REDD+ and FLEGT Processes: Case Study Analysis from Cameroon, Ghana, Liberia and the Republic of Congo. Forest Policy and Economics, 97, 83-96. https://doi.org/10.1016/j.forpol.2018.09.012

Teye, J. (2013). Corruption and Illegal Logging in Ghana. International Development Planning Review, 35, 1-19. https://doi.org/10.3828/idpr.2013.2

Tilahun, M., Damnyag, L., \& Anglaaere, L. C. (2016). The Ankasa Forest Conservation Area of Ghana: Ecosystem Service Values and On-Site REDD+ Opportunity Cost. For est Policy and Economics, 73, 168-176. https://doi.org/10.1016/j.forpol.2016.08.011

Tropenbos International (TBI) (2017). Making Knowledge Work for Forests and People. Annual Report.

Wilson, S. J., Schelhas, J., Grau, R., Nanni, A. S., \& Sloan, S. (2017). Forest EcosystemService Transitions: The Ecological Dimensions of the Forest Transition. Ecology and Society, 22, 38. https://doi.org/10.5751/ES-09615-220438

Yaduv, V. K., Srivastava, A. K., \& Khare, P. K. (2018). Tropical Forest and Ecosystems Services in Indian Context. Current World Environment, 13, 151.

https://doi.org/10.12944/CWE.13.1.14 